\title{
Universal influenza vaccination: a Mexican Expert Position Paper
}

\author{
Guillermo M. Ruiz-Palacios y Santos ${ }^{1}$, Miguel Betancourt-Cravioto², Francisco J. Espinosa-Rosales ${ }^{3}$, \\ Rodolfo Rivas-Ruiz**, Martha C. Guerrero-Almeida5 ${ }^{5}$ Ma. de Lourdes Guerrero-Almeida', \\ Marte Hernández-Porras ${ }^{6}$, Alejandro E. Macías-Hernández ${ }^{7}$, Mercedes Macías-Parra ${ }^{6}$, \\ Sarbelio Moreno-Espinosa ${ }^{8}$, Mussaret Bano-Zaidi ${ }^{9}$, Daniel E. Noyola10, José Ramos-Castañeda ${ }^{11}$, \\ Norberto Reyes-Paredes ${ }^{12}$, Romeo S. Rodríguez-Suárez ${ }^{13}$, Fortino Solórzano-Santos ${ }^{14}$ \\ and Heladio G.V. Vargas-Ramírez ${ }^{15}$
}

${ }^{1}$ Infectology Department, Instituto Nacional de Ciencias Médicas y Nutrición Salvador Zubirán, Mexico City; ${ }^{2}$ Sociedad Mexicana de Salud Pública, Cuernavaca, Morelos; ${ }^{3}$ Fundación Mexicana para Niñas y Niños con Inmunodeficiencias Primarias, AC (FUMENI), Mexico City; ${ }^{4}$ Center for Training and Clinical Research, Clinical Research Division, Instituto Mexicano del Seguro Social, Mexico City; ${ }^{5}$ Centro de Vacunación Prevenire, Morelia, Michoacán; ${ }^{6}$ Infectology Department, Instituto Nacional de Pediatría, Mexico City; Infectology Department, Universidad de Guanajuato, Guanajuato; ${ }^{8}$ Infectology Department, Hospital Infantil de México Federico Gómez, Mexico City; ${ }^{9}$ Infectious Diseases Research Unit, Hospital General Dr. Agustín O’Horán, Mérida, Yucatán; ${ }^{10}$ Microbiology Department, Faculty of Medicine, Universidad Autónoma de San Luis Potosí, San Luis Potosí; ${ }^{11}$ Center for Research on Infectious Diseases, Instituto Nacional de Salud Pública, Cuernavaca, Morelos; ${ }^{12}$ Gynecology and Obstetrics Department, Instituto Nacional de Perinatología, Mexico City; ${ }^{13}$ Fundación IMSS AC, Mexico City; ${ }^{14}$ Evidence-based Medical Research Unit, Hospital Infantil de México Federico Gómez, Mexico City; ${ }^{15}$ Department of Pediatrics, Hospital General de Zacatecas, Zacatecas. Mexico

\begin{abstract}
Influenza is a costly disease for the population. It is a cause of seasonal morbidity and mortality, epidemics and pandemics or syndemics. Given the variability of the virus, surveillance systems are implemented in order to update the strains and include them in the annual influenza vaccine. This vaccine is currently recommended in some high-risk groups. However, universal vaccination remains controversial. Objective: To evaluate the evidence and describe the position of a panel of experts on the relevance of universal vaccination against influenza virus. Material and methods: Five clinical questions were asked, whereby a systematic search of the literature in electronic sources and a Delphi panel were carried out. The evidence was analyzed, and recommendations were issued by the experts. Results: The group of experts recommends vaccinating the population starting at six months of age and include people who live with egg protein allergy, with comorbidities (diabetes, obesity, cancer), health workers and pregnant women. Conclusions: Vaccination, starting with vulnerable groups, is a necessary, ethical and cost-effective strategy. However, expanding the coverage to achieve universal vaccination could reduce the transmission of the disease and its consequences in the population.
\end{abstract}

KEY WORDS: Influenza. Vaccination. Risk groups. Pregnancy. Health professionals.

\section{Vacunación universal contra el virus de la influenza: consenso de expertos en México}

\section{Resumen}

La influenza es una enfermedad costosa para la población. Es causa de morbimortalidad estacional, epidemias y pandemias o sindemias. Debido a la variabilidad del virus, se implementan sistemas de vigilancia para actualizar las cepas e incluirlas en la vacuna antiinfluenza anual. Actualmente se recomienda esta vacuna en algunos grupos de alto riesgo. Sin embargo, la 
vacunación universal es aún controvertida. Objetivo: Evaluar la evidencia y describir la posición de un panel de expertos sobre la pertinencia de la vacunación universal contra el virus de influenza. Material y métodos: Se realizaron cinco preguntas clínicas, con las que se realizó una búsqueda sistemática de la literatura en fuentes electrónicas y un panel Delphi. Se analizó la evidencia y se emitieron recomendaciones por los expertos. Resultados: El grupo de expertos recomienda vacunar a la población desde los seis meses de edad e incluir a personas que viven con alergia a la proteína del huevo, con comorbilidades (diabetes, obesidad, cáncer), trabajadores de la salud y embarazadas. Conclusiones: La vacunación, iniciando con los grupos vulnerables, es una estrategia necesaria, ética y costo-efectiva. Sin embargo, extender la cobertura para lograr la vacunación universal podría disminuir la transmisión de la enfermedad y sus consecuencias en la población.

PALABRAS CLAVE: Influenza. Vacunación. Grupos de riesgo. Embarazo. Profesionales de la salud.

\section{Introduction}

Infections caused by the influenza virus affect $5-30 \%$ of the population, which entails 3 to 5 million cases of severe disease and 290,000 to 650,000 deaths in the world ${ }^{1}$. Vaccination is the most effective form to prevent the disease and its consequences ${ }^{1,2}$.

The vaccine has demonstrated a decrease in moderate to severe disease, hospitalizations and influenza virus transmission. Efficacy of the vaccine has been determined to be $59 \%$ (95\% confidence interval $[\mathrm{Cl}]$ : $52-72 \%)$ in children and $65 \%$ (95\% Cl: $54-73)$ in adults $>65$ years of age ${ }^{3,4}$.

With the arrival of the pandemic produced by severe acute respiratory syndrome coronavirus 2 (SARSCoV-2), the syndemic that corresponds to the interaction between two or more epidemics/pandemics present at the same time in a population became apparent ${ }^{5}$. In our country, this syndemic corresponds to the interaction caused by the SARS-CoV-2 pandemic, the epidemic of obesity, diabetes and other comorbidities, as well as the constant presence of influenza. The fight against this syndemic requires the highest number of simultaneous actions, including universal influenza vaccination.

In Mexico, the influenza vaccination strategy is focused on groups considered at high risk for the development of complications. However, expanding the coverage to other population groups remains controversial, which is why experts on the subject were summoned to evaluate the evidence and issue a consensus statement on the pertinence of universal vaccination.

\section{Methodology}

A multidisciplinary group of experts in influenza vaccination was summoned in Mexico. Using the Delphi methodology, a questionnaire was designed that was sent to the group of experts in order to obtain a pre-consensus on the aspects to discuss regarding universal vaccination.

During the face-to-face meeting, the group was shown the Delphi questionnaire result. A systematic search of the literature was carried out on electronic databases (PubMed, Bireme and Google Scholar) for each one of the topics using the PICO acronym (patients, intervention/comparison and outcomes). Each team reviewed all retrieved articles. The teams presented the results of their work on a plenary session, in which the methodology and measures of clinical relevance were taken into account. Consensus was reached for 15 of 27 topics (56\%), and thus the discussion emphasized the topics for which reaching an agreement had not been possible. In those cases, the topics were reviewed until consensus was reached. After the meeting, the editor in charge gathered the texts of each team to put together a first version of the document, which was fully discussed in a second meeting in order to obtain the final version.

\section{Results}

\section{Vaccination coverage expansion to children aged between 5 and 12 years}

\section{RECOMMENDATION}

The influenza vaccine should cover the 6 months to 12 years age group, with or without risk factors.

\section{RATIONALE}

The recommendation to expand the age groups in order to include the group of children aged between 5 and 12 years is based on the fact that they generate the highest levels of influenza transmission ${ }^{6}$. When reducing the infection rate in school-age children is 
achieved by increasing coverage, not only does the risk of contagions decrease (odds ratio [OR]: $0.7 ; 95 \%$ Cl: 0.62-0.89), but the burden of disease is also reduced in other populations not contemplated in the vaccination schedule ${ }^{3}$. Schoolchildren immunization might reduce the frequency of influenza cases among household contacts.

\section{Vaccination in the population with a history of egg allergy}

\section{RECOMMENDATION}

Children with egg allergy should be vaccinated in a health unit that has the capacity of response for the management of a possible anaphylactic reaction and that follows international vaccination guidelines. The vaccine is only contraindicated in subjects with a history of previous anaphylactic reaction.

\section{RATIONALE}

Current prevalence of egg allergy in Mexico is low $(0.4 \% \text { of the population })^{7}$. Anaphylaxis reported frequency is 1.3 cases $/ 1,000,000$. Most these events have occurred in patients with a documented history of severe allergic reactions to eggs $^{8}$. Vaccine-related anaphylactic reactions are rare due to a low ovalbumin content $(<1 \mathrm{mg} / \mathrm{dose})^{9}$. However, administering the vaccine in hospitals is recommended ${ }^{10}$.

\section{Influenza vaccination during pregnancy}

\section{RECOMMENDATION}

- All pregnant women should have the inactivated vaccine applied, regardless of the trimester of gestation.

- Women who were not vaccinated during pregnancy should receive one dose in the postpartum period or while breastfeeding.

\section{RATIONALE}

The inactivated influenza vaccine has been shown to be safe for the mother and the fetus. The influenza vaccine does not increase fetal death, congenital malformations or spontaneous abortions ${ }^{11}$. It is important to note that the administration of live virus vaccines is contraindicated during pregnancy ${ }^{12}$.
Since influenza vaccine is not recommended for < 6 months of age, the vaccine should be applied at least four weeks before delivery ${ }^{12}$. Controlled clinical trials have confirmed an efficacy of vaccination in pregnant women of $27-63 \%$ to prevent laboratory-confirmed influenza and $29 \%$ for acute respiratory disease in the newborn and infants, as previously suggested by non-randomized studies ${ }^{13,14}$. According to predictive models in our country, to reduce maternal-fetal mortality, an influenza vaccine coverage of at least $80 \%$ for pregnant women and individual vaccination of women of childbearing age is suggested ${ }^{12}$.

\section{Vaccination of health personnel in health care units}

\section{RECOMMENDATION}

All healthcare workers should receive the vaccine, universally and annually.

\section{RATionale}

Nosocomial influenza outbreaks are frequent and reach an attack rate that ranges between 12 and $60 \%{ }^{15}$.

The most important factors that contribute to nosocomial influenza outbreaks include a low vaccination rate and poor adherence to hygiene measures among health workers ${ }^{16}$. In addition, the pandemic caused a $4.2 \%$ decrease in health personnel vaccination ${ }^{17}$. In Mexico, adherence to influenza vaccination is $63.5 \%$ among health workers, which is considered subopti$\mathrm{ma}^{18}$, given that the vaccine has shown efficacy $(70$ to $90.4 \%$ ) for reducing the number of influenza infections among health workers vaccinated against influenza $A(\mathrm{H} 1 \mathrm{~N} 1)^{19,20}$.

There is still debate about mandatory influenza vaccination policies for increasing vaccination rates among health personnel, and efforts are being made to implement them in hospitals ${ }^{21}$. The benefit of vaccination in health personnel involves a decrease in infection rates, absenteeism days and costs of care ${ }^{22}$.

\section{Influenza and comorbidities}

\section{RECOMMENDATION}

All patients with comorbidities, especially diabetes mellitus (DM), asthma, chronic obstructive pulmonary disease (COPD), kidney disease, overweight and 
obesity, cardiovascular diseases and immunocompromised individuals should receive the influenza vaccine annually.

\section{RATIONALE}

Being an inflammatory disease, influenza infection in patients with comorbidities increases the risk of hospitalization and death ${ }^{23}$. People who live with diabetes benefit from vaccination for preventing hospitalization and pneumonia caused by the influenza virus and this disease, regardless of age and metabolic control status ${ }^{24}$.

In addition, the risk of hospitalization for influenza is higher in patients with cardiovascular disease (OR: 1.63; $95 \% \mathrm{Cl}: 1.33-2.02)^{25}$, asthma (OR: $2.25 ; 95 \% \mathrm{Cl}$ : 1.67-3.03) ${ }^{26}$, cancer (OR: $\left.2.25 ; 95 \% \mathrm{Cl}: 1.23-4.11\right)^{27}$, kidney disease (OR: $2.11 ; 95 \% \mathrm{Cl}: 1.48-3.01)^{28}$, obesity (BMI > 30; OR: $3.28 ; 95 \% \mathrm{Cl}$ : 1.73-5.91), as well as in people who suffer from morbid obesity (OR: 18.4; 95\% Cl: 7.83-47.4) ${ }^{29}$. Obese patients have higher susceptibility and poorer prognosis both in case of influenza and SARS-CoV-2 infection ${ }^{30,31}$.

In addition to preventing death, the vaccine prevents the risk of acute myocardial infarction by between 15 and $45 \%$ in the general population ${ }^{32}$. In patients with coronary heart disease, the vaccine reduced cardiovascular mortality (relative risk [RR]: $0.45 ; 95 \% \mathrm{Cl}$ : $0.26-0.76)^{33,34}$.

There is no conclusive information on the benefit of influenza vaccine in patients with COPD and asthma. However, its use has been associated with a decrease in exacerbations and hospitalizations ${ }^{35}$. Although information is not sufficient, COPD patients vaccinated against influenza have 37\% fewer exacerbations than those who are not vaccinated. Estimated risk is 0.82 (95\% Cl: $0.79-0.96)$ for preventing respiratory failure in COPD patients vaccinated against influen$\mathrm{za}^{36}$, which results in a $90 \%$ decrease in the cost of care for COPD exacerbations associated with hospitalization, with the vaccine being therefore cost-beneficial $^{37}$.

In patients with asthma, hospitalizations for asthma exacerbations have been observed to increase during the influenza season ${ }^{38}$. Vaccination for preventing influenza has been considered to possibly be a protective factor in asthmatic individuals, although the results are not conclusive. In practice, a more favorable evolution of vaccinated asthmatics who were hospitalized for exacerbation suggests that vaccination provides some protection (Table 1) 19,40. $^{39}$.
Table 1. Population with comorbidities that requires to be vaccinated against influenza

- Asthma 26,38,40

- Cardiovascular disease (hypertension) ${ }^{25,32,33}$

- Chronic lung disease (COPD) ${ }^{36,37}$

- Immunosuppression (including people who live with HIV,

transplant recipients, cancer patients) ${ }^{27,28,33,34}$

- Metabolic disease (including diabetes mellitus) ${ }^{24}$

- Neuromuscular disease ${ }^{12}$

- Overweight and any degree of obesity $29-31$

- Kidney disease ${ }^{28}$

COPD: chronic obstructive pulmonary disease; HIV: human immunodeficiency virus.

\section{Vaccination in patients who live with cancer}

\section{RECOMMENDATION}

All cancer patients, regardless of the treatment stage they are at, should receive the influenza vaccine.

\section{RATIONALE}

The benefit of influenza vaccination has been demonstrated in patients with neoplasms regardless of the type of cancer and treatment.

Its benefit has been demonstrated in patients with colon and rectal cancer (RR: $0.5 ; p<0.001$ ) and lung cancer (RR: 0.428; $p=0.002)^{41}$. In patients with solid tumors receiving chemotherapy, a decrease in mortality has been demonstrated (OR: 0.88 ; $95 \% \mathrm{Cl}$ : 0.77$0.99)^{42}$. In addition, it reduces the number of cancer treatment interruptions, regardless of the moment of the chemotherapy cycle in which the vaccine was applied $^{43}$.

\section{Discussion}

We have discussed current evidence and consider that the above recommendations are sound and could bring benefits in general to the Mexican population.

In addition, the influenza vaccine has been shown to be cost-effective by reducing mortality, hospital admissions and improving quality of life.

In 2018, direct medical costs in the US were estimated to be USD \$ 3.2 billion (\$1.5-\$11.7 billion), and indirect costs, $\$ 8.0$ billion (\$ 4.8-\$ 13.6 billion) $)^{44}$.

In our country, a cross-sectional cost-effectiveness study showed that achieving universal vaccination 
Table 2. Recommended groups that should receive the influenza vaccine

- Children aged between 6 months and 5 years 11 months ${ }^{12}$

- School-age children (6 to 11 years 11 months) $)^{3,6}$

- Patients who live with comorbidities: patients with asthma ${ }^{40}$, $\mathrm{COPD}^{37}$, cardiovascular disease (including hypertension) ${ }^{34}$, conditions that cause immunosuppression (cancer, transplants and HIV), metabolic diseases (particularly DM, chronic kidney disease, overweight and obesity) 24,27,28,33

- Patients with egg allergy ${ }^{9,10}$

- Adults older than 50 years ${ }^{12}$

- Pregnant women at any trimester or week of gestation ${ }^{11}$

- Women in the postpartum period, even if breastfeeding ${ }^{1}$

- Nursing home residents and their carers ${ }^{12}$

- Health workers ${ }^{15,17}$

COPD: chronic obstructive pulmonary disease; HIV: human immunodeficiency virus; DM: diabetes mellitus.

coverage could prevent 154,143 emergency department admissions and 97,637 hospitalizations, with annual savings of 3.90 to 111.99 million USD ${ }^{45}$.

The expert consensus determined that vaccination expansion to schoolchildren and adolescents is recommendable. This is similar to what has been recommended in other countries such as Japan ${ }^{6}$. In Mexico, vaccination expansion to this group of children was shown to be a cost-effective action that could save up to 111.9 million US dollars ${ }^{46}$.

It is important to recognize that, for economic reasons, specific factors should be considered in order to prioritize gradual inclusion of the entire population. The group of experts adheres to the universal recommendation proposed by international health agencies and, in the case of the Public Sector in Mexico, requests, to the extent possible, for a budget to be available that allows at least to meet the goal of expanding influenza vaccination to children aged from 6 months to 12 years and to the groups with comorbidities at higher risk.

Finally, this group of experts emphasizes the need for influenza vaccination prior to the next 2022-2023 season, since during the pandemic produced by SARS-CoV-2, the prevalence of most respiratory viruses that commonly circulate and cause acute respiratory disease has been minimal or non-existent and there is no knowledge on what the course of influenza reemergence will be in the near future and its consequences in a population whose defenses against influenza have most likely been diminished.

Based on current scientific evidence, the recommended priority groups that should receive the influenza vaccine are described in table 2.

\section{Acknowledgments}

The authors thank the participants of this panel, who assisted at each one of the stages of the Delphi Panel, and the librarians who assisted with the bibliography.

\section{Funding}

This work was funded by Sanofi Pasteur, Mexico. The sponsor had no role in the design of the manuscript, or in the collection, analysis and interpretation of data, or in the writing of the manuscript.

\section{Conflict of interests}

The authors declare that they have no conflicts of interest.

\section{Ethical disclosures}

Protection of human and animal subjects. The authors declare that no experiments were performed on humans or animals for this research.

Confidentiality of data. The authors declare that they have followed the protocols of their work center on the publication of patient data.

Right to privacy and informed consent. The authors declare that no patient data appear in this article.

\section{References}

1. Qualls N, Levitt A, Kanade N, Wright-Jegede N, Dopson S, Biggerstaff M, et al. Community Mitigation Guidelines to Prevent Pandemic Influenza - United States, 2017. MMWR Recomm Reports. 2017;66(1):1-34.

2. Grohskopf LA, Sokolow L, Broder K, Walter EB, Fry AM, Jernigan DB. Prevention and control of seasonal influenza with vaccines: Recommendations of the Advisory Committee on Immunization Practices - United States, 2018-19 Influenza Season. MMWR Recomm Reports. 2018;67(03):1-20.

3. Sánchez-Ramos EL, Monárrez-Espino J, Noyola DE. Impact of vaccination on influenza mortality in children. Vaccine. 2017;35(9):1287-92.

4. Tricco AC, Chit A, Soobiah C, Hallett D, Meier G, Chen MH, et al. Comparing influenza vaccine efficacy against mismatched and matched strains: a systematic review and meta-analysis. BMC Med. 2013;11:153.

5. Antonio-Arques V, Franch-Nadal J, Caylà JA. Diabetes and tuberculosis: a syndemic complicated by COVID-19. Med Clin (Barc). 2021;S00257753(21)00208-6.

6. Reichert TA, Sugaya N, Fedson DS, Glezen WP, Simonsen L, Tashiro M. The Japanese Experience with vaccinating schoolchildren against Influenza. N Engl J Med. 2001;344(12):889-96.

7. Góngora-Meléndez MA, Magaña-Cobos A, Montiel-Herrera JM, Pantoja-Minguela CL, Pineda-Maldonado ML, Piñeyro-Beltrán EE. Alergia a las proteínas del huevo en edad pediátrica. Rev Alerg Mex. 2015;62(3):234-50.

8. Moro PL, Woo EJ, Marquez P, Cano M. Monitoring the safety of high-dose, trivalent inactivated influenza vaccine in the vaccine adverse event reporting system (VAERS), 2011 - 2019. Vaccine. 2020;38(37):5923-6.

9. Des Roches A, Paradis L, Gagnon R, Lemire C, Bégin P, et al.; PCIRN (Public Health Agency of Canada/Canadian Institutes of Health Research Influenza Research Network). Egg-allergic patients can be safely vaccinated against influenza. J Allergy Clin Immunol. 2012;130(5):1213-6. 
10. Greenhawt M, Turner PJ, Kelso JM. Administration of influenza vaccines to egg allergic recipients: A practice parameter update 2017. Ann Allergy Asthma Immunol. 2018;120(1):49-52.

11. Macias AE, Precioso AR, Falsey AR, Global Influenza Initiative. The Global Influenza Initiative recommendations for the vaccination of pregnant women against seasonal influenza. Influenza Other Respi Viruses. 2015;9(Suppl 1):31-7.

12. Secretaría de Salud. Conoce los grupos prioritarios para vacunarse contra la influenza [Internet]. Gobierno de México, Secretaría de Salud [accessed: January 2021]. Available at: https://www.gob.mx/salud/articulos/conoce-los-grupos-prioritarios-para-vacunarse-contra-la-influenza.

13. Tapia MD, Sow SO, Tamboura B, Tégueté I, Pasetti MF, Kodio M, et al Maternal immunisation with trivalent inactivated influenza vaccine for prevention of influenza in infants in Mali: a prospective, active-controlled observer-blind, randomised phase 4 trial. Lancet Infect Dis. 2016;16(9):1026-35

14. Steinhoff MC, Katz J, Englund JA, Khatry SK, Shrestha L, Kuypers J, et al. Year-round influenza immunisation during pregnancy in Nepal: a phase 4, randomised, placebo-controlled trial. Lancet Infect Dis. 2017;17(9):981-9

15. Javaid W, Ehni J, Gonzalez-Reiche AS, Carreño JM, Hirsch E, Tan J, et al. Real-time investigation of a large nosocomial influenza A outbreak informed by genomic epidemiology. Clin Infect Dis. 2020;30:ciaa1781.

16. Vanhems $P$, Bénet $T$, Munier-Marion E. Nosocomial influenza: encouraging insights and future challenges. Curr Opin Infect Dis. 2016;29(4):366-72.

17. Kang M, Clark S, Mendoza S, Arocha D, Cutrell JB, Perl TM, et al. Influenza vaccination among healthcare personnel during the coronavirus disease 2019 (COVID-19) pandemic. Infect Control Hosp Epidemiol. 2021;9:1-2

18. Ochoa-Hein E, Gutiérrez-López EN, Torres-Erazo DS, Núñez-Caamal NJ, Martínez-Longoria CA, García-Bonilla LA, et al. Factors associated with influenza vaccination acceptance in Mexican healthcare workers: A multicenter cross-sectional study. Prev Med. 2021;148:106560.

19. Dini G, Toletone A, Sticchi L, Orsi A, Bragazzi NL, Durando P. Influenza vaccination in healthcare workers: A comprehensive critical appraisal of the literature. Hum Vaccin Immunother. 2018;14(3):772-89.

20. Maltezou HC, Theodoridou K, Ledda C, Rapisarda V, Theodoridou M Vaccination of healthcare workers: is mandatory vaccination needed? Expert Rev Vaccines. 2019;18(1):5-13.

21. Stead M, Critchlow N, Eadie D, Sullivan F, Gravenhorst K, Dobbie F. Mandatory policies for influenza vaccination: Views of managers and healthcare workers in England. Vaccine. 2019;37(1):69-75.

22. Laris González A, Villa Guillén M, López Martínez B, Gamiño Arroyo AE, Moreno Espinosa S, Jiménez Juárez RN, et al. Influenza-like illness in healthcare personnel at a paediatric referral hospital: Clinical picture and impact of the disease. Influenza Other Respi Viruses 2018;12(4):475-81.

23. Lansbury LE, Brown CS, Nguyen-Van-Tam JS. Influenza in long-term care facilities. Influenza Other Respi Viruses. 2017:11(5):356-66.

24. Remschmidt C, Wichmann O, Harder T. Vaccines for the prevention of seasonal influenza in patients with diabetes: systematic review and meta-analysis. BMC Med. 2015;13:53.

25. Clar C, Oseni Z, Flowers N, Keshtkar-Jahromi M, Rees K. Influenza vaccines for preventing cardiovascular disease. Cochrane Database Syst Rev. 2018;(5):CD005050.

26. Cates CJ, Rowe BH. Vaccines for preventing influenza in people with asthma. Cochrane Database Syst Rev. 2013;(2):CD000364.

27. Eliakim-Raz N, Vinograd I, Zalmanovici Trestioreanu A, Leibovici L, Paul M. Influenza vaccines in immunosuppressed adults with cancer. Cochrane Database Syst Rev. 2013;10:CD008983.
28. Ma BM, Yap DYH, Yip TPS, Hung IFN, Tang SCW, Chan TM. Vaccination in patients with chronic kidney disease-Review of current recommendations and recent advances. Nephrology (Carlton). 2021;26(1):5-11.

29. Moser JS, Galindo-Fraga A, Ortiz-Hernández AA, Gu W, Hunsberger S, Galán-Herrera JF, et al.; La Red ILI 002 Study Group. Underweight, overweight, and obesity as independent risk factors for hospitalization in adults and children from influenza and other respiratory viruses. Influenza Other Respir Viruses. 2019:13(1):3-9.

30. Murphy R, Fragaszy EB, Hayward AC, Warren-Gash C. Investigating obesity as a risk factor for influenza-like illness during the 2009 H1N1 influenza pandemic using the Health Survey for England. Influenza Other Respi Viruses. 2017;11(1):66-73.

31. Guglielmi V, Colangeli L, D’Adamo M, Sbraccia P. Susceptibility and severity of viral infections in obesity: Lessons from influenza to COVID-19. Does leptin play a role? Int J Mol Sci. 2021;22(6):3183.

32. Maclntyre CR, Mahimbo A, Moa AM, Barnes M. Influenza vaccine as a coronary intervention for prevention of myocardial infarction. Heart. 2016;102(24):1953-6.

33. Clar C, Oseni Z, Flowers N, Keshtkar-Jahromi M, Rees K. Influenza vaccines for preventing cardiovascular disease. Cochrane Database Syst Rev. 2018;5:CD005050.

34. Raffoul M, Lin KW. Influenza vaccination for the prevention of cardiovascular disease. Am Fam Physician. 2016;93(5):357-8.

35. Bekkat-Berkani R, Wilkinson T, Buchy P, Dos Santos G, Stefanidis D, Devaster J-M, et al. Seasonal influenza vaccination in patients with COPD: a systematic literature review. BMC Pulm Med. 2017;17(1):79.

36. Kopsaftis Z, Wood-Baker R, Poole P. Influenza vaccine for chronic obstructive pulmonary disease (COPD). Cochrane Database Syst Rev. 2018:6:CD002733.

37. Huang HH, Chen SJ, Chao TF, Liu CJ, Chen TJ, Chou P, et al. Influenza vaccination and risk of respiratory failure in patients with chronic obstructive pulmonary disease: A nationwide population-based case-cohort study. J Microbiol Immunol Infect. 2019;52(1):22-9.

38. Gerke AK, Yang M, Tang F, Foster ED, Cavanaugh JE, Polgreen PM. Association of hospitalizations for asthma with seasonal and pandemic influenza. Respirology. 2014;19(1):116-21.

39. Suárez-Varela MM, Llopis A, Fernandez-Fabrellas E, Sanz F, Perez-Lozano MJ, Martin V, et al. Asthma and influenza vaccination in elderly hospitalized patients: Matched case-control study in Spain. J Asthma. 2018:55(4):391-401.

40. Vasileiou E, Sheikh A, Butler C, El Ferkh K, von Wissmann B, McMenamin J, et al. Effectiveness of influenza vaccines in asthma: A systematic review and meta-analysis. Clin Infect Dis. 2018;65(8):1388-95.

41. Bitterman R, Eliakim-Raz N, Vinograd I, Zalmanovici Trestioreanu A, Leibovici L, Paul M. Influenza vaccines in immunosuppressed adults with cancer. Cochrane Database Syst Rev 2018;2(10):CD008983.

42. Vollaard A, Schreuder I, Slok-Raijmakers L, Opstelten W, Rimmelzwaan G, Gelderblom H. Influenza vaccination in adult patients with solid tumours treated with chemotherapy. Eur J Cancer. 2017;76:134-43.

43. Lehrer S, Rosenzweig KE. Influenza vaccination in patients with cancer. Cancer. 2017;123(7):1272-3.

44. Putri WCWS, Muscatello DJ, Stockwell MS, Newall AT. Economic burden of seasonal influenza in the United States. Vaccine. 2018:36(27):3960-6.

45. Tapia-Conyer R, Betancourt-Cravioto M, Montoya A, Falcón-Lezama JA, Alfaro-Cortes MM, Saucedo-Martínez R. A call for a reform of the influenza immunization program in Mexico: Epidemiologic and economic evidence for decision making. Vaccines (Basel). 2021;9(3):286.

46. Falcón-Lezama JA, Saucedo-Martínez R, Betancourt-Cravioto M, Alfaro-Cortes MM, Bahena-González RI, Tapia-Conyer R. Influenza in the school-aged population in Mexico: burden of disease and cost-effectiveness of vaccination in children. BMC Infect Dis. 2020;20(1):240. 